\title{
EXPERIMENTAL ANALYSIS OF THE DIELECTROPHORETIC FORCES INFLUENCE ON HEIGHT OF RISE OF FLUID IN A CAPILLARY SYSTEM FOR BOILING CONTROL IN MICRO- CHANNEL
}

\begin{abstract}
Flow control in microchannels is one of the key issues in many areas of modern technology, such as medicine, bio-engineering, chemistry and, in recent years, also in problems of thermodynamic processes control. This paper presents the results of experimental studies on the dynamics of liquid movement between the walls of a microchannel, which is the effect of the electric field applied to the walls (the dielectrophoresis phenomenon). The presented results fill a gap in the literature, being also an important material for the determination of the device key parameters, such as the height of the microchannel electrodes, frequency and amplitude of applied voltage, the selection of periods with and without voltage, all of which affect the operation of the device.
\end{abstract}

Keywords: flow rate control, microchannel, dielectrophoresis

\section{Introduction}

Understanding and controlling of fluid-flow at microscale is of great importance due to growing range of its applications including nowadays, among others, medicine, bio-engineering and chemistry. Microfluidic devices are also used for heat transfer in microelectronic systems as well as in refrigeration, cooling and OCR systems. To enhance a capillary-force driven flow which is characteristic for microfluidic devices the electric field is often employed to induce electrowetting, electrocapillarity or dielectrophoretic (DEP) effects [7]. A microchannel flow controller based on DEP effect has been proposed by us lately $[4,5]$. The pressure-driven flow in a channel with rectangular cross-section is

\footnotetext{
${ }^{1}$ Autor do korespondencji/corresponding author: Marcin Lackowski, Institute of Fluid Flow Machinery, Polish Academy of Sciences, ul. Fiszera 12, 80-231 Gdańsk, tel. 58 5225256, e-mail: mala@imp.gda.pl

2 Jarosław Karwacki, Institute of Fluid Flow Machinery PAN, e-mail: jkarwacki@imp.gda.pl
} 
enhanced by capillary and DEP forces in this device. It was shown that by changing the electric voltage applied to the electrodes placed on vertical walls of the channel the liquid flow rate can be effectively regulated. However, optimization of this device, particularly with the goal to control its time-response properties, is required if the controller is to be treated as a part of a feed-back system for temperature regulation. To this end, knowledge of the influence of the forces on the fluid height of rise is necessary because its value is correlated with the liquid flow rate in the controller [4-6].

A time evolution of the height of rise for capillary driven flow was analyzed theoretically first for tubes of circular cross-sections [10]. Classical LucasWashburn equation takes into account viscous, surface tension and gravitational forces. More advanced models incorporate inertial force and entrance pressure loss effects [1,9]. Newer papers account also parallel-plate and rectangular capillaries $[9,11]$. A generalized theoretical analysis [12] gives the results which agree very well with experimental results for different geometries, dimensions and fluids. Despite the fact that the effect of the capillary rise seems a very well understood subject, to our knowledge, there is no analysis on the temporal evolution of the height of rise for the case when DEP forces exist together with capillary forces. Papers that deal with the electric field effects on the capillary dynamics are devoted to electrowetting [2] or electrocapillarity [8] effects only.

The goal of our work is to perform experimental analysis of the influence of the DEP forces on the temporal dependence of the height of rise in capillary system made of two parallel plates constituting two electrodes. The rate of rise is essential for the proper design (selection of the electrodes height) of the flow control system based on a solution proposed by Lackowski in his patent [3]. Knowledge of height of rise dynamics also allows for the selection of the timedependent parameters of the microfluidic flow controller.

\section{Laboratory stand}

The paper presents the results of experiments conducted on a test stand schematically shown in figure 1 . The stand consists of a microchannel, high voltage supply system and optical system for recording and time analysis of the rise rate. The main element of the test stand is a model microchannel consisting of two copper electrodes forming its walls and set at the distance of $300 \mu \mathrm{m}$. The sidewall electrodes are made of copper. High voltage is applied to each of the sidewalls. Microchannel model (Fig. 2) is immersed in a specially prepared tank ensuring that the increase of the liquid height between the electrodes causes only a minimal lowering of the liquid level in the tank due to its large volume.

Voltage supply system consisted of arbitrary waveform generator type RIGOL DG 1032 and high-voltage power amplifier type TREK 10/10BS-HS triggered by TTL signal from the image recording controller. Rectangular AC voltage signal was fed to the system electrodes. To control and monitor the sys- 
tem operation, an oscilloscope type Tektronix TDS 2022B was used. Linear LED lamp CCS LNSP SW-200 of high luminosity was also utilized during the experiments.

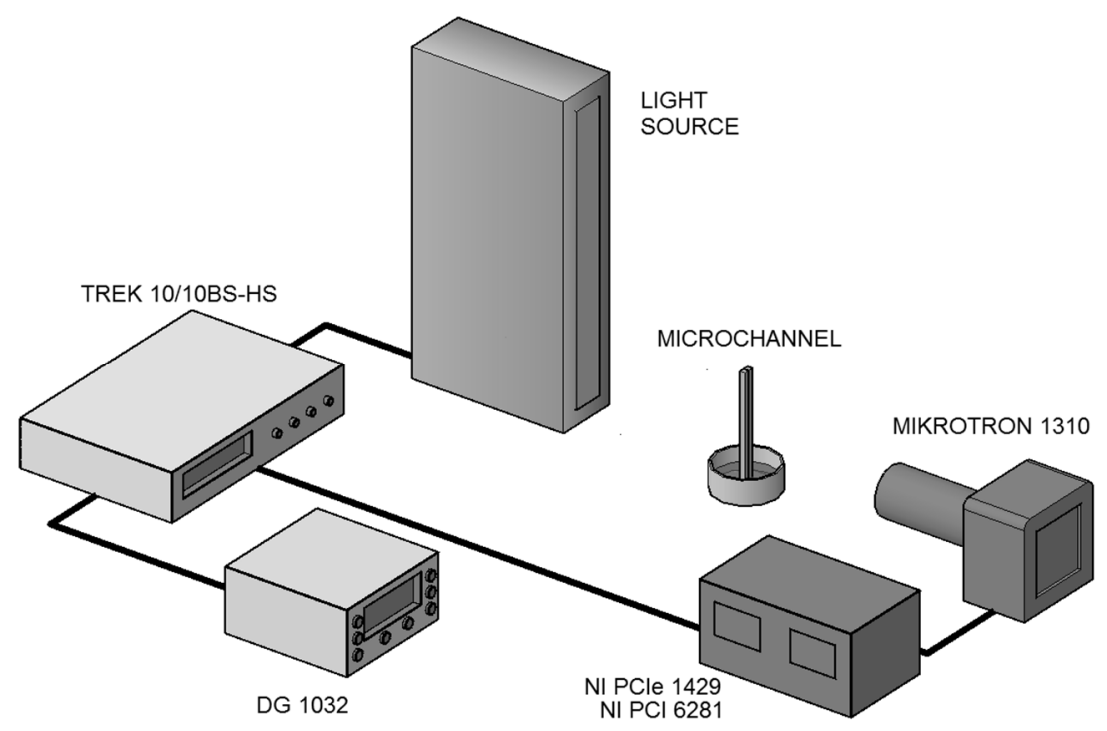

Fig. 1. Schematic view of the laboratory test stand

Fig. 2. Schematic view of the microchannel in which time evolution of the height of rise was investigated

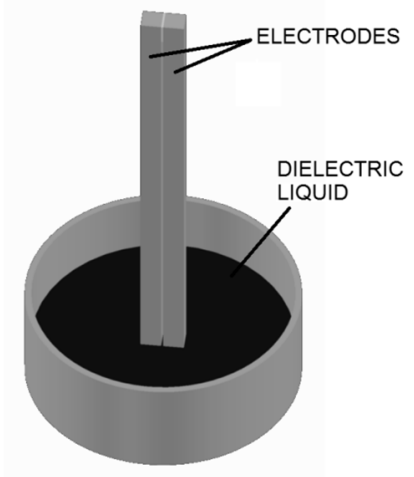

The data recording system was based on the use of high-speed monochrome camera Mikrotron 1310 equipped with a Schneider XENOPLAN 2.0/28-0901 lens with a set of extension rings and data acquisition system based on the boards NI 1429 and NI PCI 6281. The systems of data acquisition and video image recording were synchronized. Image analysis was done in LabVIEW environment with NI VISION Development Module. In the experiments, isopropanol was used as a working fluid. 


\section{Experimental results}

The height of rise changes over time for different voltages applied to the microchannel electrodes are shown in figure 3. The frequency of the applied rectangular waveform of alternating voltage was $500 \mathrm{~Hz}$. During the measurements, the current flowing in the space between the electrodes forming the microchannel sidewalls was also controlled. Dependence of the height of rise on the applied voltage is shown in figure 4 for a rectangular alternating voltage with a frequency of $500 \mathrm{~Hz}$. It shows the liquid height of rise increase with the growth of the voltage applied to the electrodes - the channel walls.

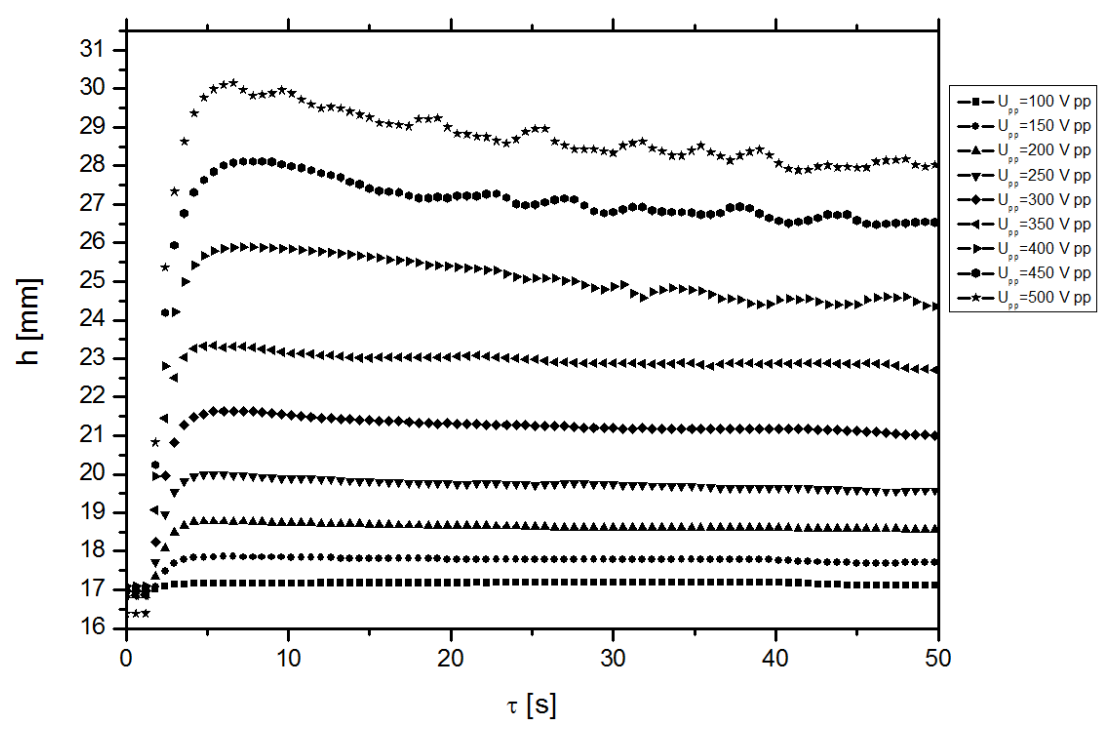

Fig. 3. Liquid height of rise in microchannel of $300 \mu \mathrm{m}$ width; the frequency of the applied alternating voltage was equal to $500 \mathrm{~Hz}$; the voltage was measured peak-to-peak

It follows from the relationships shown in figure 3 that the achievement of the maximum liquid heigh of rise in the interelectrode space requires approximately 2 seconds. On the other hand, relatively very high value of the rise indicates that in the design process of the systems based on the phenomenon of dielectrophoresis it is suitable to reduce the height of the electrodes which reduces the range of the regulation but ensures faster response. This is particularly important in the application of the examined phenomenon to control the process of bubble formation during boiling where the lifting velocity is of particular importance. For different voltage applied to the electrodes, the maximum level of liquid is achieved in similar time.

Time evolution of the electric current in the space between the electrodes (microchannel walls) is shown in figure 5. It is seen that the current in the inte- 
relectrode space increases with the applied voltage. The measured values of the interelectrode current are low enough to not initiate the boiling of the liquid flowing between the microchannel electrodes. Exemplary photographs showing the height of the dielectric liquid pulling in the interelectrode space for different values of applied voltage are shown in figure 6 .

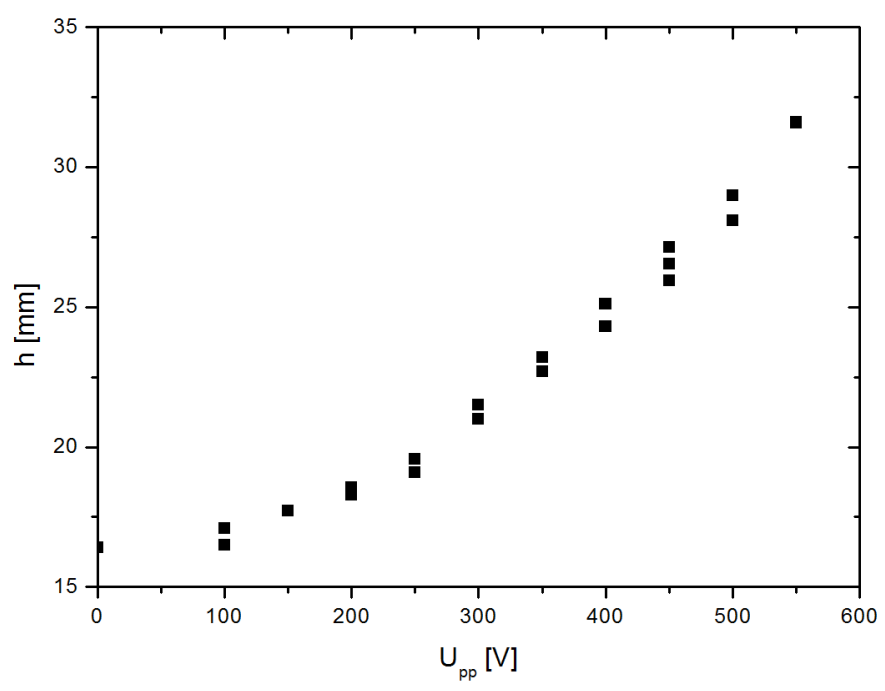

Fig. 4. Height of rise as a function of the voltage applied to the electrodes

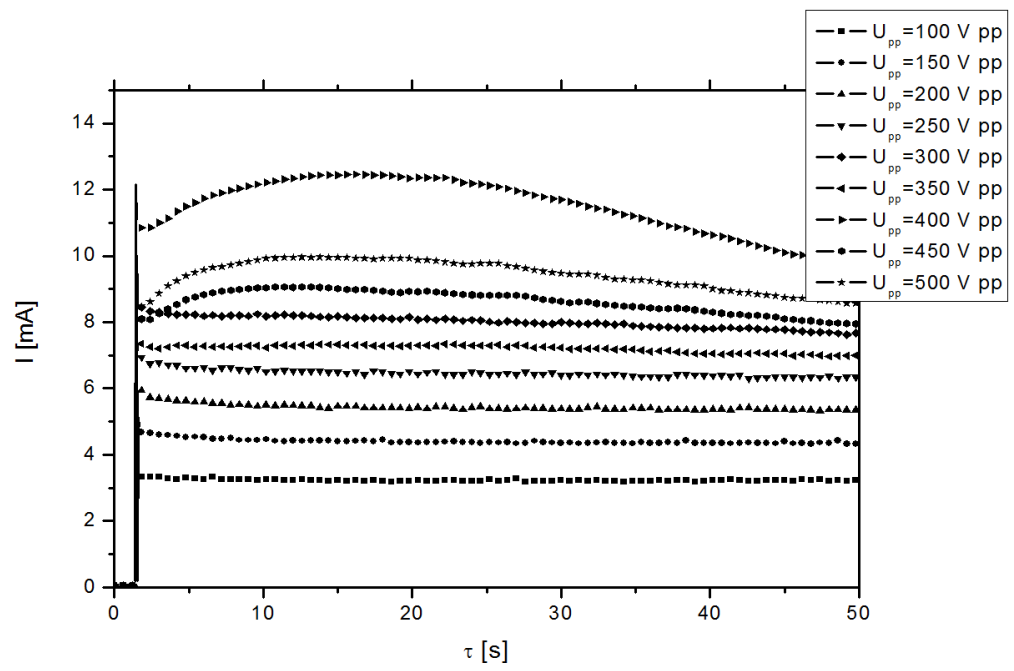

Fig. 5. Time evolution of the electric current for selected values of interelectrode voltage in the investigated microchannel; power supply frequency was $500 \mathrm{~Hz}$ 


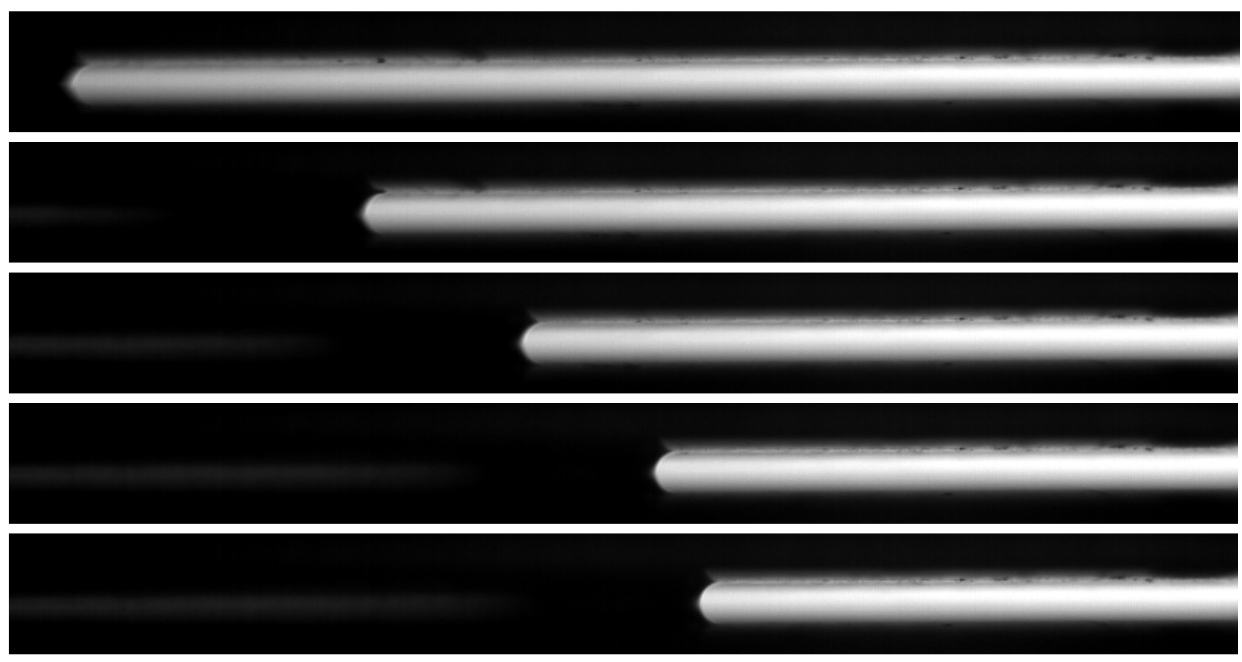

Fig. 6. Example photographs of the liquid rise in the investigated microchannels; top image shows the initial liquid level, succeeding images were taken at time intervals of $0.5 \mathrm{~s}$

\section{Conclusions}

The paper presents the results of the experimental measurements of the dielectric liquid height of rise in the interelectrode space of a microchannel. As follows from the literature review included in the introduction, such studies in terms of the liquid rise dynamics were not carried out, yet. The results show the temporal response capabilities of devices employing the dielectrophoresis phenomenon which particularly refers to the flow controllers and systems controlling the process of boiling. The data acquired during the investigation of liquid rise dynamics allow for the optimal selection of the target devices operating parameters. Moreover, the gathered results fill the gaps in the literature and in the basic knowledge on the dielectrophoresis phenomenon.

\section{Acknowledgement}

This research has been supported by National Science Centre within the Project No. 2012/05/B/ST8/02742.

\section{References}

[1] Hamraoui A., Nylander T.: Analytical approach for the Lucas-Washburn equation, J. Colloid Interface Sci., 250 (2002) 415-421.

[2] Hong S.J., Hong J., Seo H.W., Lee S.J., Chung S.K.: Fast electrically driven capillary rise using overdrive voltage, Langmuir, 31(2015) 13718-13724.

[3] Lackowski M.: Device for adjusting flow control rate of liquid, Patent PL 223329. 
[4] Lackowski M.: Dielectrophoresis flow control of volatile fluids in microchannels, J. Thermal Sci., 24 (2015) 1-5.

[5] Lackowski M., Krupa A., Butrymowicz D.: Dielectrophoresis flow control in microchannels, J. Electrostatics, 71(2013) 921-925.

[6] Lackowski M., Nowakowska H.: Numerical modelling of dielecrophoresis effect in microchannel flow controller - comparison of calculation methods, Przegląd Elektrotechniczny, 8 (2016) 95-99.

[7] Pethig R.: Review article - dielectrophoresis: status of the theory, technology, and applications, Biomicrofluidics, 4 (2010) 022811.

[8] Prins M.W.J., Welters W.J.J., Weekamp J.W.: Fluid control in multichan-nel structures by electrocapillary pressure, Science, 291 (2001) 277-280.

[9] Waghmare P.R., Mitra S.K.: A comprehensive theoretical model of capillary transport in rectangular microchannels, Microfluidics Nanofluidics, 12 (2012) 53-63.

[10]Washburn E.W.: The dynamics of capillary flow, Physical Review, 17 (1921) 273.

[11]Wu P., Zhang H., Nikolov A., Wasan D.: Rise of the main meniscus in rectangular capillaries: experiments and modeling, J. Colloid Interface Sci., 461 (2016) 195-202.

[12]Xiao Y., Yang F., Pitchumani R.: A generalized analysis of capillary flows in channels, J. Colloid Interface Sci., 298 (2006) 880-888.

\section{EKSPERYMENTALNA ANALIZA WPEYWU SIEY DIELEKTRO- FORETYCZNEJ NA WYSOKOŚĆ PODNOSZENIA CIECZY W SYSTEMIE KAPILARNYM DO KONTROLI PROCESU WRZENIA W MIKROKANALE}

\section{Streszczenie}

Kontrola przepływu w mikrokanałach jest jednym z kluczowych zagadnień w wielu obszarach współczesnej technologii, szczególnie w medycynie, bioinżynierii, chemii, a w ostatnich latach również w kontroli procesów termodynamicznych. Niniejszy artykuł prezentuje wyniki badań eksperymentalnych dynamiki ruchu cieczy pomiędzy ściankami mikrokanału. Ruch ten jest wywołany przyłożeniem do ścianek mikrokanału napięcia pola elektrycznego (zjawisko dielektroforezy). Zaprezentowane wyniki wypełniają lukę w literaturze przedmiotu, są również ważnym materiałem dla określenia kluczowych parametrów urządzenia takich jak wysokość elektrod mikrokanału, częstotliwość i wartość napięcia zasilającego, a także wybór przedziałów czasu pomiędzy okresami przykładania napięcia i jego braku. Wszystkie wymienione parametry wpływają na pracę urządzenia.

Słowa kluczowe: kontrola szybkości przepływu, mikrokanał, dielektroforeza

DOI: $10.7862 / \mathrm{rm} .2017 .06$

Otrzymano/received: 24.10 .2016

Zaakceptowano/accepted: 12.01.2017 
